\title{
Epilogue: After Deren
}

\author{
Elinor Cleghorn
}

M

y eyes are locked with his, but around the edges, the iris of my vision, there is a circle of dancing movement. There is, encircling us, also, a cylinder of song and deep beats. And there is a third unseen, unheard circle about us, too ... a tension, a watching ... And we two, dancing in the center. I dance as I have never danced before. It is not more violent, nor more expertly, cleverly achieved. It is simply correct in a very final sense, in the fact that there is neither decision nor triumph, but only the immaculate execution of an inevitability. Yet, I feel as if a transparent level of consciousness were superimposed upon this reality; that there is something about these movements which is still my own; in the shorter length of my limbs, in the longer drop of my hair, in some attitude of my fingers which articulates my own singular history of ecstasy and pain.'

Maya Deren wrote this passage, or something close to it, in her diary in 1947, while in Haiti on the first of her several trips to observe, film, record, and participate in the rituals of Voudoun. The passage describes her inauguration into the rhythms of possession: induced by dance, compelled by drum and song. She published a very personal account of this "first contact with Voudoun,"2 based on these diary notes, in December 1948 in the important yet short-lived art and literature magazine The Tiger's Eye. Titled "The Artist as God in Haiti," Deren's contribution was included with others by Max Ernst, Joan Miro, Georges Bataille, Robert Motherwell, and Mark Rothko, to name only a few. Barnett Newman acted as the magazine's art director for its second and third issue, and his renowned essay "The Sublime is Now" was originally published alongside Deren's piece. The Tiger's Eye was named after William Blake's 1794 poem "The Tyger." It focussed on artists' own reflections on their processes, imposed no particular editorial framework, and sought to foster a sympathetic yet critical readership. The inclusion of Deren's diary-based account as exemplary of such a journalistic metier goes some way towards countering the claims of P. Adams Sitney and Stan Brakhage that her fascination with Voudoun "essentially ... destroyed her as an artist."3 The editors of The Tiger's Eye, painter John Stephan and his wife Ruth, provided a context for Deren's meditations on Voudoun that was attuned to the significance she afforded to her participatory involvement with ritual activity. For Deren, possession was process. It enabled her to inhabit the modes of intense expression that she sought to "convert," to borrow Stephen Heath's term, into her cinema. ${ }^{4}$ With her Bolex in hand and her eye behind its lens, she indeed dared, as William Blake imagined, "to frame" ritual's "fearful symmetry."

In her lifetime Deren published methodological and theoretical essays, statements on filmic form, and comments on her own films across a variety of other journals and magazines, including New Directions, Daedalus, and Mademoiselle. The year after her death, the New York-based journal Filmwise dedicated an issue to memories of Maya. The impact of her loss reverberates through the celebratory, anecdotal, and poetic eulogies by Brakhage, Rudolph 
Arnheim, Willard Maas, Parker Tyler, Charles Boultenhouse, and Jerry Tallmer, amongst others. This 1962 publication is a poignant commemoration of Deren by the community of artists and writers with whom she was not only professionally but also personally connected. At the same time, it documents a very particular moment in time, when the journal served as the ideal format for the galvanisation of collective energies circulating around the production and presentation of independent and experimental cinema.

This issue of The International Journal of Screendance is dedicated to Deren some fifty years after the New York filmic avant-garde memorialised her as their peer, agent, mobiliser and "mother." Our title, "After Deren," exemplifies the extent to which, at this particular moment in time and within the ever-expanding context of screendance's own galvanic energies, Deren's legacy continues to reverberate. It seems fitting, therefore, to reflect in epilogue upon the way that the journal, a conversational format, a gathering of voices, so appositely enables a retracing of the contours, as Claudia Kappenberg puts it, of the "multifaceted crystalline figure we call Deren."

I dance opposite one woman, then a man, then a girl, then another. They seem to wish to mirror with me, and there is a curious graciousness in my accepting and permitting this with one then another, for these are the preliminaries in some act which, in its accomplishment, will bless all those who have partaken of it ... suddenly our mirroring movements slip into the accord of complete unity. Meaning takes flight from mile post to mile post. The cadence of the singing is sharper and sharper... My left foot seems rooted and I try not to fall but when I do it is without fear. People hold me up. I feel my shoes being removed. Then I am stood up again like a doll set on its own feet ... My reaching arms meet a voice and cling to it and that which has been travelling up my leg reaches my mind and obliterates it. ${ }^{6}$

At the time of writing 'The Artist as God in Haiti' Deren had advanced her "choreocinema" from the elliptical, solo male dance of A Study in Choreography for Camera, to the mythological dance-drama Ritual in Transfigured Time (1945/46) and the dualistic, parabolic Meditation on Violence (1948). Deren came to filmmaking with a lifelong love for dance, and a closely held academic interest in ritual dance forms. As the editors of The Legend of Maya Deren emphasise, the favourable response to Study by dance critics such as Walter Terry, as well as John Martin, whose public enthusiasm for Deren's innovations bore the term "choreocinema," significantly expanded her audiences, and compelled her to further pursue the possibilities for the radical enmeshment of dance and film. At the time of its release, Study provoked generative debates within the spheres of dance and film criticism. While Study was neither the first example of dance in cinema, nor the inauguration of filmmaking as a choreographic practice, it was nonetheless an exceptionally provocative catalyst for the opening up of conversations across disciplines about the "potentialities of the dance in motion pictures." In Dance Observer magazine in 1946 the sculptor Richard Lippold exalted Study as the "first conscientious and consistent effort" to use the technological specificities of the filmic apparatus to free the dancing body from the "earth bound" limitations of space, time and physicality. In Film News earlier that year, writer and producer Newton Melzer celebrated Deren's evolution of "a new choreographic concept, one that stems from the camera's mobility and versatility and her own editing principles." The journalist Louise Levitas, also in 1946, found in the floating leaps and "strange, spiral turns" of Study a "kind of magic," and marvelled at the ways Deren's camera movements embodied those of her dancer..$^{10}$ These and other responses appeared in various journals 
and magazines in the months preceding Deren's first public solo screening at New York's Provincetown Playhouse.

Taken together, these writings emblematise the ways that Deren's emancipation of the strictures of theatrical dance through the capacities of cinema instantiated "choreocinema," "filmic dance," and "dance film" as subjects of discourse. This issue of The International Journal of Screendance is testament to the continuing capacity of Deren's cinema to further the parameters of a mode of discourse that her specific approach, at that very particular time, undeniably mobilised. Furthermore, the essays, interviews and reviews in "After Deren" reflect the ways that Deren's treatment of film as dance has yielded, and will continue to yield, multiconversational, inter-disciplinary, ever-moving formulations of screendance as discourse.

"After Deren" is, in many ways, the continuation of a series of conversations: of those unfolding between artists, academics and audiences at the BFI season Maya Deren: 50 Years On; of those which heralded Deren as the proponent of a "virtually new medium" in 1946; of those opened up by the contributions to Maya Deren and the American Avant-Garde; and of those instantiated by the inclusion of Deren's writings in journals and magazines across disciplines during and after her life. Most importantly, this issue focuses on Deren in order to continue the conversations happening right here, within The International Journal of Screendance, "a living space for serious, lively, on-going debate about the art form."11 Deren might not be the "mother" of screendance, but she is undoubtedly one of the art form's most illuminating cynosures. In the orbit of this issue she guides a constellation of satellites. Sophie Mayer and Lucy Reynolds extend their conversations from the BFI symposium Maya Deren: New Reflections; Silvina Szperling and Narcisa Hirsch speak to us from Buenos Aires; Sarah Keller and Barbara Hammer from New York; Aura Satz and Jayne Parker from London; Andrew James from Plymouth; Eleni Tranouli from Paris; Harmony Bench from Ohio; Douglas Rosenberg from Madison, Wisconsin; and Claudia Kappenberg from Brighton.

By offering these rich, original, insightful and reflective interpretations of Deren's resounding relevance in The International Journal of Screendance, we are by no means enclosing her legacy within any pre-determined parameters, which might be imposed to dogmatically define "screendance." Rather, as editors Douglas Rosenberg and Claudia Kappenberg elucidated in their editorial comment for Volume 1, "we have chosen to use the term screendance to broadly describe a field, while noting that there are no hard and fast criteria for a definition of screendance." Within this open, thoughtful, yet critically rigorous context, readings and analyses of Deren's filmmaking methodologies, theoretical and personal writings, ethnographic practices, advocacy of cinema as art, and activism for independent practice contribute to the furthering of "screendance as a form of research," precisely because neither Deren's cinema, nor screendance, is limited to the constitution of dancing bodies as cinematic entities. "After Deren" exemplifies the journal's ambitions to explore screendance as a locus for the examination of "the interrelationships of composition, choreographic language, and meanings of body, movement, space, and time ... in the context of contemporary cultural debates about artistic agency, practice as theory, and interdisciplinarity." ${ }^{12}$ It has been a privilege to have a hand in the choreography of this special issue-for the process of planning, editing and compiling a journal, particularly one for which movement is the medium, is akin to a choreographic act. From its roots in the Ancient Greek word khoreia meaning both the dance itself and the circular enclosure in which it takes place, choreography resounds in chorus. The choreographic intention of 
"After Deren" is not to encircle but to circulate Maya Deren, through the scholarly re-visions, theoretical examinations, artists' interviews and reviews, all of which, we hope, will resonate. Thank you to all our contributors for your generosity of thought and time. We look forward to continuing the conversation.

The form is complete. In the tiny room neither of us is ourselves. He, knowing, and I, learning through a tuning stretched tight to the most subtle expectation, realize in collaboration a complete, a perfect mythology. To achieve the impersonal perfectly is a personal triumph...13

\section{Notes}

1. Deren, "The Artist as God in Haiti," 118, 119.

2. Ibid.

3. Brakhage, Film at Wit's End, 111. See also P. Adams Sitney, Visionary Film, 40. Sitney purports that Deren's art "diminished" when she moved from "the powerful element of psycho-drama" towards the embodiment of ritualistic principles in Meditation on Violence (1948) and The Very Eye of Night (1955), her final two films made in the midst of her participatory thrall to Voudoun.

4. Heath, Questions of Cinema, 179.

5. The final stanza of Blake's "The Tyger": "Tyger! Tyger! burning bright/ In the forests of the night/ What immortal hand or eye/ Dare frame thy fearful symmetry?" See Blake 51.

6. Deren, "The Artist as God in Haiti," 119.

7. Leaf, "Loose Leaves from a Dance Notebook," 285.

8. Lippold, “Dance and Film," 59.

9. Melzer, "Three Abandoned Films," 390.

10. Levitas, "How to Make Your Own Movies on a Shoestring," 16.

11. Editorial comment, The International Journal of Screendance, 3-4.

12. Ibid., 1.

13. Deren," The Artist as God in Haiti," 123

\section{References}

Blake, William. "The Tyger" (1794). In Songs of Innocence and Songs of Experience, edited by David Price. London: R. Brimley Johnson, 1901.

Brakhage, Stan. Film at Wit's End. New York: Documentext/McPherson and Company, 1989.

Clark, VèVè, Millicent Hodson, and Catrina Neiman. The Legend of Maya Deren:Documentary Biography and Collected Works. Vol. 1, Part 2, "Chambers" (1942-47). New York: Anthology Film Archives, 1984.

Deren, Maya. "The Artist as God in Haiti." The Tiger's Eye 1, no. 6 (December 1948): 115-24.

Heath, Stephen. Questions of Cinema. London: Macmillan, 1981.

Kappenberg, Claudia and Douglas Rosenberg. "Editorial Comment: Screendance: Practice in Print." The International Journal of Screendance 1 (Summer 2010): 1-4.

Leaf, Earl. "Loose Leaves from a Dance Notebook." Dance Magazine (July 1945). In The Legend of Maya Deren: Documentary Biography and Collected Works. Vol. 1, Part 2, "Chambers" (1942-1947), edited by Clark et. al., 285. New York: Anthology Film Archives, 1984

Levitas, Louise. "How to Make Your Own Movies on a Shoestring." P.M. (Tuesday, March 19, 1946): 16.

Lippold, Richard. "Dance and Film: A Review in the Form of a Reflection." Dance Observer (May 1946): 58-60.

Melzer, Newton E. "Three Abandoned Films." In The Legend of Maya Deren: Documentary Biography and Collected Works, Vol. 1, Part 2, "Chambers", edited by Clark et. al., 389-391. New York: Anthology Film Archives, 1984.

Sitney, P. Adams. Visionary Film: The American Avant-Garde, 1943-2000. Third edition. Oxford: Oxford University Press, 2002. 